\title{
Kegagalan Analisis Laporan Keuangan Dalam Memprediksi Kebangkrutan BPR/BPRS di Indonesia
}

\section{Suwandi Miskak}

* Email: miskaksuwandi@yahoo.com

a Institut Pertanian Bogor

\section{Riwayat artikel:}

- Diterima 08 September 2019

- Direvisi 4 November 2019

- Disetujui 13 Januari 2020

- Tersedia online 1 Mei 2020

Kata kunci: ARIMA; CAR; bank gagal; peramalan; penyalahgunaan; tata kelola.

JEL Classification : M14, M28

\begin{abstract}
Since operated in 2005 until 2017, Indonesian Deposit Insurance (LPS) has liquidated 84 BPR/BPRS which were declared as failed banks by Bank Indonesia (BI) / Financial Services Authority (OJK). The cause of the failure of the BPR/BPRS was that the bank cannot meet the minimum capital adequacy ratio (CAR) due to losses suffered by the bank. The bank losses were caused fraud by owner, management and employees. Losses were recognized in the financial statements after they were found by BI/OJK. By using ARIMA, we forecast quarterly CAR data before a BPR/BPRS is determined as a bank under special supervision to determine the ability of CAR data to predict whether the bank will be placed as a bank under special supervision. This research result shows the difference between estimated CAR and actual CAR is significant. This means that CAR data calculated based on financial statements cannot predict the BPR/BPRS will be determined as a bank under special supervision, which in turn has the potential to become a failed bank.
\end{abstract}

Keyword: ARIMA; CAR; failed bank; forecasting; fraud; good corporate governance

\begin{abstract}
Abstrak. Sejak beroperasi pada 2005 hingga 2017, LPS telah melikuidasi 84 BPR/BPRS yang dinyatakan sebagai bank gagal oleh BI/OJK. Penyebab kegagalan BPR/BPRS adalah bahwa bank tidak dapat memenuhi rasio kecukupan modal minimum (CAR) karena kerugian yang dialaminya. Kerugian bank disebabkan fraud oleh pemilik, manajemen, dan karyawan. Kerugian diakui dalam laporan keuangan setelah ditemukan oleh BI/OJK. Kami melakukan forecasting data CAR triwulanan sebelum BPR/BPRS ditempatkan dalam pengawasan khusus untuk menentukan kemampuan prediksi data CAR apakah bank akan ditempatkan sebagai bank dalam pengawasan khusus menggunakan teknik ARIMA. Hasil penelitian menunjukkan bahwa perbedaan antara perkiraan CAR dan CAR aktual adalah signifikan. Hal ini berarti bahwa data CAR yang dihitung berdasarkan laporan keuangan tidak dapat digunakan untuk memprediksi apakah BPR/BPRS akan ditempatkan dalam pengawasan khusus, yang pada akhirnya berpotensi menjadi bank yang gagal. *
\end{abstract}




\section{PENDAHULUAN}

Di Indonesia terdapat dua jenis bank yaitu bank umum dan Bank Perkreditan Rakyat (BPR). Untuk BPR yang menjalankan kegiatan perbankan berdasarkan prinsip syariah disebut Bank Pembiayaan Rakyat Syariah (BPRS). Perbedaan utama antara bank umum dan BPR/BPRS antara lain adalah ada tidaknya fasilitas jasa lalu lintas transaksi keuangan. Bank umum memfasilitasi jasa lalu lintas pembayaran seperti kliring, inkaso, valuta asing, dan transfer sedangkan BPR tidak menyediakan fasilitas tersebut.

Tren jumlah BPR/BPRS sejak 2012 sampai dengan 2017 mengalami penurunan dari 1.825 BPRS/BPRS menjadi 1.729 BPR/BPRS. Selain karena merjer/akuisisi, penurunan terjadi karena penutupan bank. Walaupun terjadi penurunan jumlah BPR/BPRS, Dana Pihak Ketiga (DPK) yang berhasil dihimpun mengalami pertumbuhan yang cukup signifikan dari 2012 sampai 2017 yaitu mencapai $9 \%$ rata-rata pertahun.

Dari sisi asset, pertumbuhan aset BPR/BPRS sejak 2012 sampai dengan 2017 mencapai 126\% atau $25,25 \%$ pertahun, dengan rincian sebagaimana yang tertulis pada Tabel 1 .

TABEL l. Aset BPR/BPRS dan Bank Umum

\begin{tabular}{|l|r|r|r|r|r|r|}
\hline Total Aset & Des 2012 & Des 2013 & Des 2014 & Des 2015 & Des 2016 & Des 2017 \\
\hline $\begin{array}{l}\text { BPR/BPRS } \\
\text { (RpTriliun) }\end{array}$ & $60,42(1 \%)$ & $77,38(2 \%)$ & $89,88(2 \%)$ & $101,71(2 \%)$ & $122,66(2 \%)$ & $136,79(2 \%)$ \\
\hline $\begin{array}{l}\text { Bank Umum } \\
\text { (RpTriliun) }\end{array}$ & $4.262,59(99 \%)$ & $4.954,4798 \%)$ & $5.65,15(98 \%)$ & $6.132,58(98 \%)$ & $7.086,30(98 \%)$ & $7.811,81(98 \%)$ \\
\hline Jumlah & $4.323,01(100 \%)$ & $5.031,85(100 \%)$ & $5.705,03(100 \%)$ & $6.234,29(100 \%)$ & $7.208,96(100 \%)$ & $7.948,6(100 \%)$ \\
\hline
\end{tabular}

Dari data tersebut menunjukkan bahwa pertumbuhan aset BPR/BPRS jauh di atas pertumbuhan dana pihak ketiga. Hal ini berarti pertumbuhan aset BPR/BPRS ditopang lebih banyak dari sumber pendanaan selain dana pihak ketiga. Peningkatan permodalan BPR/BPRS untuk memperbaiki tingkat solvabilitas bank juga dapat menjadi sumber pembiayaan untuk meningkatkan aset. Jika dibandingkan dengan pertumbuhan aset bank umum yang hanya naik rata-rata 17\% per tahun sejak 2012 sampai 2017, maka pertumbuhan aset BPR/BPRS jauh lebih tinggi.

Sejak LPS beroperasi sampai dengan akhir 2017, tercatat dari total 1.915 BPR/BPRS yang pernah/masih beroperasi, sejumlah 184 bank pernah ditetapkan dalam status Bank Dalam Pengawasan Khusus (BDPK), dan 91 bank telah dicabut izin usahanya oleh BI/OJK termasuk self liquidation. Hasil kajian yang dilakukan oleh LPS pada tahun 2016, penyebab utama dari banyaknya BPR/BPRS yang dicabut izin usahanya (likuidasi) tersebut adalah karena terjadinya tindakan penyimpangan (fraud) yang dilakukan baik oleh pemilik, pengurus maupun karyawan bank. Tindakan penyimpangan tersebut antara lain dalam bentuk penyaluran kredit fiktif, angsuran kredit yang tidak disetorkan oleh petugas bank, pencairan deposito tanpa sepengetahuan nasabah, dan kredit yang tidak didukung dengan agunan yang memadai. TABEL 2 menjelaskan uraian penyebab bank gagal serta dampak kerugian finansialnya. 
TABEL 2: Penyebab BPR/BPRS Gagal (2006-2016) (dampak dalam jutaan rupiah)

\begin{tabular}{llrrr}
\hline No & \multicolumn{1}{c}{ Penyebab Penyimpangan } & \multicolumn{2}{c}{ Jumlah Kejadian } & $\begin{array}{r}\text { Dampak Kejadian } \\
\text { (finansial) }\end{array}$ \\
\cline { 3 - 4 } & & \multicolumn{2}{c}{ (\%) } & 807,104 \\
\hline 1 & Penyalahgunaan kredit & 73 & $31 \%$ & 87,631 \\
2 & Kredit macet, rekayasa kol, dan & 62 & $26 \%$ & \\
& PPAP & & & 7,183 \\
3 & Koreksi penilaian agunan & 10 & $4 \%$ & - \\
4 & Pelanggaran BPMK & 7 & $3 \%$ & 37,065 \\
5 & Penggunaan RRA, kerugian, dan & 37 & $15 \%$ & 4,076 \\
& penggelapan & & & $2 \%$ \\
6 & Kesulitan likuiditas & 5 & $2 \%$ & $1,152,342$ \\
7 & Penyalahgunaan simpanan & 45 & $19 \%$ & \\
\hline & Total & 244 & $100 \%$ & \\
\hline
\end{tabular}

Sumber: Kajian LPS (2016), diolah.

Sebelum ditemukan adanya fraud oleh OJK, BPR/BPRS masih mencatat laba dengan tingkat solvabilitas yang ditunjukkan dengan angka CAR jauh diatas angka minimum. Hal ini berarti bank masih solvent. Setelah BI/OJK melakukan koreksi atas laporan keuangan akibat terjadinya fraud tersebut, bank langsung membukukan kerugian dan akibatnya CAR bank menjadi turun signifikan bahkan menjadi negatif.

BPR/BPRS mempublikasikan laporan keuangan secara triwulanan melalui website OJK. Dalam laporan publikasi tersebut juga disampaikan rasio-rasio pokok keuangan antara lain CAR, NPL, LDR, dan BOPO. CAR digunakan sebagai alat ukur tingkat solvabilitas bank. CAR ini juga dipakai OJK untuk menentukan apakah bank ditetapkan dalam status pengawasan normal, pengawasan intensif, dan pengawasan khusus. Sebelum berlakunya POJK No. 19/POJK.03/2017 tentang Penetapan Status dan Tindak Lanjut Pengawasan BPR/BPRS, status pengawasan berdasarkan PBI No.l1/20/PBI/2009 tentang Tindak Lanjut Penanganan Terhadap Bank Perkreditan Rakyat Dalam Status Pengawasan Khusus hanya dikenal dua kategori yaitu pengawasan normal dan pengawasan khusus. Dalam hal BPR/BPRS dinilai mengalami kesulitan yang membahayakan kelangsungan usahanya maka BPR/BPRS tersebut ditetapkan dalam status pengawasan khusus. Dikatakan sebagai BPR/BPRS yang membahayakan kelangsungan usahanya apabila memenuhi kriteria yaitu (a) CAR kurang dari 4\%; dan/atau (b). Cash Ratio rata-rata selama 6 (enam) bulan terakhir kurang dari 3\%.

Dengan ditemukannya penyebab kegagalan BPR/BPRS adalah fraud, maka sangat menarik untuk diteliti apakah data series CAR BPR/BPRS yang dihitung berdasarkan laporan keuangan publikasi dapat digunakan untuk memprediksi bank akan ditetapkan sebagai bank dalam pengawasan khusus yang selanjutnya menjadi bank gagal.

\section{TINJAUAN PUSTAKA}

\subsection{Teori Kebangkrutan}

Kebangkrutan perusahaan adalah suatu proses (Outtecheva, 2007). Proses kebangkrutan dimulai dengan early impairment karena penurunan kualitas aset, kemudian terjadi pemburukan kinerja yang mengakibatkan permasalahan cash flow sehingga perusahaan gagal untuk memenuhi kewajibannya baik jangka pendek maupun jangka panjang. Apabila nilai aset perusahaan tidak dapat memenuhi seluruh kewajibannya, hal ini berarti perusahaan memiliki ekuitas negatif. Dalam kondisi demikian, perusahaan dinyatakan insolvent dan akhirnya menjadi bankrupt. Proses financial distress ditampilkan pada GAMBAR 1 . 


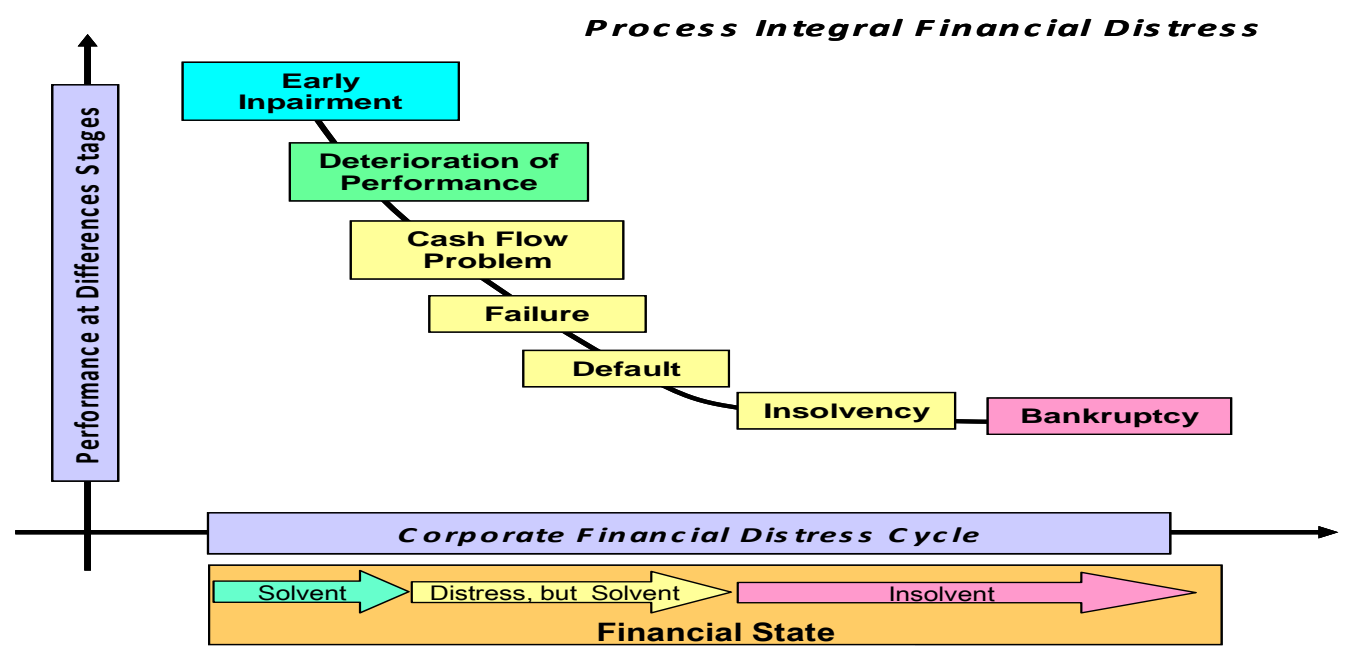

Sumber : Pranowo (2010), modifikasi dari Outtecheva (2007)

Sebagaimana proses kebangkrutan perusahaan yang ditampilkan pada GAMBAR 1 bahwa perusahaan terlebih dahulu akan mengalami kesulitan likuiditas yang lebih jauh nantinya akan memberikan peluang untuk tidak mampu menjalankan usaha operasional perusahaan dengan baik sehingga akan terjadi kebangkrutan pada perusahaan tersebut.

Sejalan dengan Outtecheva, bahwa kebangkrutan sebagai sebuah situasi dimana arus kas tidak dapat memenuhi untuk membayar kewajiban saat ini (Wruck, 1990). Sementara Whitaker (1999) menegaskan bahwa kebangkrutan terjadi karena perusahaan mengalami persoalan keuangan yang sudah lama.

\subsection{Kualitas Informasi Laporan Keuangan}

Laporan keuangan merupakan suatu pencatatan atau laporan yang mencakup informasi keuangan sebuah perusahaan. Umumnya laporan keuangan digunakan untuk mengetahui kinerja perusahaan dalam suatu periode tertentu, dan digunakan baik oleh pihak internal perusahaan maupun eksternal perusahan. Laporan keuangan biasa digunakan oleh internal perusahaan sebagai informasi yang dijadikan rujukan dalam menentukan suatu keputusan bagi pihak manajemen sedangkan bagi pihak eksternal, umumnya laporan keuangan digunakan sebagai informasi dalam hal mengambil keputusan investasi. Untuk itu, kualitas informasi keuangan menjadi hal yang sangat penting.

Ikatan Akuntan Indonesia juga menjabarkan tentang karakteristik kualitas laporan keuangan sebagaimana yang dinyatakan dalam PSAK yaitu dapat dipahami dan relevan. Informasi memiliki kualitas relevan kalau dapat mempengaruhi keputusan ekonomi pemakai dengan membantu mereka mengevaluasi peristiwa masa lalu, masa kini atau masa depan, menegaskan, atau mengkoreksi hasil evaluasi mereka di masa lalu. Peran informasi dalam peramalan (predictive) dan penegasan (confirmatory) berkaitan satu sama lain.

Informasi posisi keuangan dan kinerja di masa lalu seringkali digunakan sebagai dasar untuk memprediksi posisi keuangan dan kinerja masa depan dan hal-hal lain yang langsung menarik perhatian pemakai, seperti pembayaran dividen dan upah, pergerakan harga sekuritas dan kemampuan perusahaan untuk memenuhi komitmennya ketika jatuh tempo. Untuk memiliki nilai prediktif, informasi tidak perlu harus dalam bentuk ramalan eksplisit. Namun demikian, kemampuan laporan keuangan untuk membuat prediksi dapat ditingkatkan dengan menampilkan informasi tentang transaksi dan peristiwa masa lalu. Misalnya, nilai prediktif laporan laba rugi dapat ditingkatkan kalau pos-pos penghasilan atau beban yang tidak biasa, abnormal dan jarang terjadi diungkapkan secara terpisah. 
Informasi memiliki kualitas andal (reliable) jika bebas dari pengertian yang menyesatkan, kesalahan material, dan dapat diandalkan pemakainya sebagai penyajian yang tulus atau jujur (faithful representation) dari yang seharusnya disajikan atau yang secara wajar diharapkan dapat disajikan. Informasi mungkin relevan tetapi jika hakikat atau penyajiannya tidak dapat diandalkan maka penggunaan informasi tersebut secara potensial dapat menyesatkan (IAI, 2015).

\subsection{Tingkat Kesehatan Bank}

Peraturan Bank Indonesia No.13/1/PBI/201l tentang Penilaian Tingkat Kesehatan Bank Umum menegaskan bahwa bank wajib melakukan penilaian tingkat kesehatan bank secara individual dengan menggunakan pendekatan risiko (Risk-Based Bank Rating) dengan cakupan penilaian terhadap faktor profil risiko (risk profile); good corporate governance (GCG); rentabilitas (earnings); dan permodalan (capital). Penilaian terhadap faktor profil risiko merupakan penilaian terhadap risiko inheren dan kualitas penerapan manajemen risiko dalam operasional bank terhadap 8 (delapan) risiko yaitu (1) risiko kredit; (2) risiko pasar; (3) risiko likuiditas; (4) risiko operasional; (5) risiko hukum; (6) risiko stratejik; (7) risiko kepatuhan; dan (8) risiko reputasi. Penilaian terhadap faktor GCG merupakan penilaian terhadap pelaksanaan prinsip-prinsip GCG. Penilaian terhadap faktor rentabilitas earnings meliputi penilaian terhadap kinerja earnings sumber-sumber earnings, dan sustainability earnings sedangkan penilaian terhadap faktor permodalan (capital) meliputi penilaian terhadap tingkat kecukupan permodalan dan pengelolaan permodalan.

Penilaian tingkat kesehatan untuk BPR dan BPRS mengacu pada ketentuan yang diatur dalam Surat Keputusan Direksi Bank Indonesia No. 30/12/KEP/DIR tanggal 30 April 1997 dan PBI No.9/17/PBI/2007 tanggal 4 Desember 2007. Terdapat lima faktor yang dinilai dalam tingkat kesehatan BPR/BPRS, yaitu (1) Permodalan (rasio modal terhadap aktiva tertimbang menurut risiko); (2) Kualitas aktiva produktif (rasio aktiva produktif yang diklasifikasikan terhadap aktiva produktif dan rasio penyisihan penghapusan aktiva produktif yang dibentuk terhadap penyisihan penghapusan aktiva produktif yang wajib dibentuk); (3) Manajemen (manajemen umum dan manajemen risiko); (4) Rentabilitas (rasio laba terhadap rata-rata volume usaha dan rasio biaya operasional terhadap pendapatan operasional); (5) Likuiditas (rasio alat likuid terhadap hutang lancar dan rasio kredit terhadap dana yang diterima).

Dari kelima faktor tersebut, hanya satu faktor yang bersifat kualitatif dan non keuangan yaitu faktor manajemen. Faktor manajemen terdiri atas manajemen umum dan manajemen risiko. Manajemen umum meliputi strategi, struktur, sistem dan kepemimpinan sedangkan manajemen risiko mencakup risiko likuiditas (liquidity risk), risiko kredit (credit risk), risiko operasional (operational risk), risiko hukum (legal risk), dan risiko pemilik dan pengurus (ownership and managership risk).

\section{KAJIAN PENELITIAN TERDAHULU}

Penelitian yang berhubungan analisis kegagalan perusahaan telah banyak dilakukan, baik yang secara teoritis maupun analitis. Umumnya obyek penelitian berupa bank umum dan perusahaan non-lembaga keuangan. Hingga saat ini, penelitian dalam memprediksi kegagalan BPR/BPRS jumlahnya masih sangat terbatas.

Merton (1974) memperkenalkan model kegagalan suatu perusahaan dengan modifikasi BlackScholes Model mengenai harga opsi. Model Merton tersebut digunakan oleh banyak peneliti terdahulu yang salah satunya adalah Tudel dan Young (2003) untuk mengetahui risk default dari suatu perusahaan-perusahaan di Inggris. Penelitian dengan metode serupa juga dilakukan oleh Hadad, Santoso, Besar, dan Rulina (2004) serta menunjukkan hasil bahwa Model Merton dapat memberikan sinyal yang baik untuk menganalisis default risk terhadap perusahaan dengan jenis industri sektor pertanian yang terdaftar di Bursa Efek Jakarta. 
Thomson (1991) menganalisis kegagalan bisnis dan kebangkrutan bank umum di USA dengan memprediksikan alasan kegagalan bank tersebut menggunakan analisis rasio keuangan CAMEL.

Penelitian terkait kegagalan bank juga dilakukan oleh Ozili (2017) dengan sampel berupa 231 bank di Eropa pada periode tahun 2004-2014. Data penelitian yang digunakan adalah PDB yang diperoleh dari World Economic Forum. Hasil penelitian Ozili menyimpulkan bahwa (1) bank-bank di Eropa menggunakan indikator fee income untuk memberikan kelancaran dalam laba perusahaan baik bagi perusahaan yang kemungkinan kecil akan gagal dan bank-bank yang kemungkinan besar akan gagal; (2) adanya korelasi yang positif antara interest income dan non-interest income yang mengindikasikan peningkatan risiko sistematis karena berkurangnya manfaat diversifikasi; (3) fee income pada bank-bank kecil bersifat prosiklis dengan kondisi ekonomi berfluktuasi tetapi tidak untuk bank-bank besar; (4) earnings management dapat meningkatkan pendapatan secara signifikan yang bergantung pada ukuran bank di Eropa pada masa pasca-krisis.

Penelitian Cole dan White (2012) untuk mengetahui mengapa dari 265 bank terdapat 117 bank komersial gagal selama krisis di tahun 2009 dengan model regresi logit. Hasil dari penelitian menunjukkan bahwa kegagalan bank yang kemudian dicabut izin usahanya selama tahun 2009 adalah sama sebagaimana yang terjadi pada tahun 1985-1992. Probabilitas kegagalan bank sangat besar pada bank yang mengalokasikan pinjaman yang lebih tinggi untuk pembangunan, pengembangan, commercial mortgages, dan multi-family mortgages. Sebaliknya, bank dengan pengalokasian yang lebih besar kepada investasi sekuritas memiliki kemungkinan gagal yang lebih kecil. Beck (2011) melakukan penelitian dengan menggunakan data kegagalan bank di Amerika Serikat, Inggris, dan Jerman selama tahun 1991-1997. Hasil penelitian menunjukkan adanya korelasi antara hukum dan tradisi (rule of law) dimana negara-negara yang diberi skor atas 'aturan hukum' memberikan kecenderungan lebih kecil dalam kegagalan perusahaan. Selain itu, disimpulkan bahwa negara-negara yang menerapkan standar akuntansi yang lebih ketat memiliki tingkat kerentanan yang lebih rendah dalam hal penyebab terjadinya kegagalan pada bank-bank tersebut.

Ekinci dan Erdal (2016) melakukan penelitian dalam memprediksi kegagalan bank terhadap 17 bank yang mengalami kegagalan finansial akibat krisisi keuangan pada tahun 1998 dan 2001. Penelitian dilakukan menggunakan 35 rasio keuangan yang berdasarkan capital, asset quality, manajemen, penghasilan, likuiditas, dan sensitivity ratio pada sistem CAMELS. Sistem konvensional yang digunakan menghasilkan model berupa ensemble learning model dan hybrid ensemble learning model. Hasil penelitian menunjukkan bahwa tingkat prediksi yang semakin baik berdasarkan klasifikasi, sensitivitas, dan area di bawah kurva ROC dengan menggunakan hybrid ensemble learning model.

Calabrese dan Giudici (2013) melakukan penelitian untuk memprediksi kegagalan bank di Italia dengan mengusulkan model baru berdasarkan faktor makroekonomi dan mikro ekonomi. Penelitian dengan menerapkan model regresi untuk data biner berdasarkan teori nilai ekstrim menghasilkan nilai yang lebih efektif daripada model regresi logistik klasik. Hal ini disebabkan pemanfaatan informasi dalam ekor dari distribusi default. Hasil penelitian menunjukkan pula bahwa secara signifikan faktor mikroekonomi yang termasuk juga di dalam regulasi permodalan dapat menjelaskan kegagalan secara tepat, sedangkan faktor makroekonomi hanya berpengaruh secara relevan ketika kegagalan tidak hanya terjadi pada ketentuan default tetapi juga terkait pula dalam hal merger dan akusisi. Dalam hal ini, model yang didasari teori nilai ekstrim (extreme value theory) melebihi nilai prediksi apabila dibandingkan dengan model regresi logistik klasik.

Ooghe, Spaenjers, dan Vandermoere (2009) menyimpulkan bahwa teknik statistik kurang memberikan gambaran tentang prosedur memprediksi kegagalan pada perusahaan di Belgia. Kondisi demikian disebabkan oleh pemilihan variabel dan penentuan koefisien sering 
menyebabkan overfitting. Hal ini juga terlihat bahwa 'tanda-tanda yang diharapkan' dari variabel terkadang diabaikan dan kerangka teoritis yang mendasari suatu model statistik sebagian besar tidak ada. Penelitian ini membangun model baru yaitu 'Simple-Intuitive Model' (SIM). Dalam model ini, delapan variabel yang digunakan ditransformasikan ke dalam Logit yang kemudian diberikan bobot yang sama untuk tiap variabel. Selanjutnya dilakukan pengujian dua sampel berupa satu dan tiga tahun sebelum kegagalan (year prior to failure). Hasil dari kinerja yang terbaik dari model simple-intuitive adalah sebanding dengan model statistik yang lebih kompleks.

Bani, Zadehbagher, dan Saberimanesh (2014) melakukan penelitian kegagalan bank di Iran. Data yang digunakan adalah 17 bank umum dan swasta di Iran dengan periode sejak tahun 2008-2012. Variabel dependen yang digunakan adalah kemampuan keuangan (financial capabilities) perusahaan bangkrut atau gagal sedangkan variabel independen adalah rasio keuangan (financial ratios). Hasil penelitian menunjukkan bahwa model Zmisky dapat lebih memprediksi kegagalan banyak bank di Iran dibandingkan dengan model Toffler yang lebih konservatif. Analisis prediksi kegagalan ini umum dilakukan sebagai keputusan dalam berinvestasi bagi investor di Iran dengan melihat unpaid principal dan interest risk terhadap permodalan mereka ke arah yang lebih minimum.

Bashir, Javed, dan Iqbal (2015) melakukan penelitian kegagalan bisnis di pasar uang Karachi dengan menggunakan model Altman Z-Score. Jenis industri dari perusahaan yang diteliti adalah bidang konstruksi, kimia, makanan, teknik, dan industri otomotif. Data perusahaan yang digunakan adalah 104 perusahaan yang terdaftar di Bursa Efek Karachi (Pakistan), dengan variabel yang diukur adalah indikator keuangan terkait penilaian kesehatan keuangan perusahaan pada periode tahun 2010-2012. Tes McNemar dan tes Kappa yang digunakan menunjukkan bahwa adanya hubungan yang siginifikan antara status sebenarnya dari perusahaan dan status yang diprediksi terkait kegagalan yang terjadi pada perusahaan. Penelitian ini juga menyimpulkan bahwa model Altman Z-Score merupakan alat prediksi yang baik ketika digunakan pada penelitian pada perusahaan-perusahaan di Pakistan dan tingkat signifikan dari hasil prediksi model Altman dalam memprediksi kegagalan dan tidak gagalnya perusahaan mencapai $81 \%$.

Hasil penelitian Konstituanto (2012) terhadap probabilitas kegagalan bank dari aspek manajemen dan keuangan di Indonesia menunjukkan bahwa Model Merton (model yang digunakan untuk menganalisis risiko kredit pada debitur) dapat menunjukkan bahwa tingginya tingkat probabilitas kegagalan bank umum di Indonesia yang disebabkan pengelolaan efisiensi bank yang masih dinilai lemah

Penelitian lainnya terkait kebangkrutan dengan Model Merton dilakukan oleh Wibowo (2017) yang melakukan penelitian mengenai metode pengukuran probabilitas kebangkrutan bank dan analisis hubungannya dengan diversifikasi sumber pendapatan. Hasil dari penelitian menunjukkan bahwa Model Merton dapat menunjukkan probabilitas kebangkrutan perbankan di Indonesia yang dipengaruhi oleh diversifikasi pendapatan dengan data yang digunakan adalah harga saham pada pasar industri perbankan di Indonesia dari tahun 20102015

Ohlson (1980) melakukan penelitian untuk memprediksi kegagalan terhadap 105 perusahaan yang pailit dan 2.058 perusahaan yang tidak pailit. Alat analisis yang digunakan oleh Ohlson adalah analisis Logit, dan hasil penelitiannya menunjukkan bahwa 7 rasio keuangan yang digunakan pada analisis Logit mampu dengan tepat dalam mengidentifikasi perusahaan yang akan bangkrut.

Singh dan Singh (2014) melakukan penelitian pada bank di India untuk mengidentifikasi sinyal yang menyebabkan merger di masa yang akan datang pada bank di India apakah dikarenakan paksaan atau secara sukarela. Model penelitian yang digunakan adalah model CAMELS (Capital, Asset Quality, Management, Earning, Liquidity, Sensitivity to Market) dengan studi 
kasus yaitu pra dan pasca Global Trust Bank dan Centurion Bank of Punjab diakuisisi. Hasil penelitian menunjukkan bahwa variabel penting pada penelitian ini yaitu berupa NPAs to total advances, capital adequacy ratio, operationg profits to working funds, net interest margin, return on equity, dan return on assets pada 3-4 tahun pra akusisi kedua bank tersebut menghasilkan kinerja yang memburuk (ke arah negatif). Model CAMELS juga dapat menunjukkan bahwa early warning system yang dilakukan pada bank di India dapat memberikan kemungkinan posisi keuangan ke arah yang positif selama bank mematuhi prinsip kehati-hatian dengan baik.

Hasil penelitian Wilopo (2006) mengenai prediksi kebangkrutan bank dengan menggunakan model CAMEL, Log. Assets, dan variabel dummy menunjukkan bahwa secara keseluruhan tingkat prediksi variabel-variabel yang digunakan dalam penelitian ini tinggi (lebih dari 50\% sebagai cut-off value-nya) namun terdapat tipe kesalahan bahwa kekuatan prediksi untuk bank yang dilikuidasi adalah nol persen. Hal ini disebabkan dari sampel bank yang dilikuidasi, semuanya diprediksikan tidak dilikuidasi. Hal yang menarik dari kesimpulan penelitian ini adalah bahwa kegagalan bank di Indonesia tidak dapat diprediksi dengan sempurna apabila hanya menggunakan model CAMEL.

Penelitian Aryati dan Balafif (2007) terhadap laporan keuangan dari 60 bank sehat dan 14 bank tidak sehat di Indonesia selama periode 2005-2006, dengan menggunakan rasio-rasio CAMEL menyimpulkan bahwa rasio NPL memiliki pengaruh yang signifikan terhadap probabilitas sehat dan tidak sehatnya bank sedangkan rasio CAR, ROA, ROE, LDR, dan NIM menunjukkan hasil yang tidak signifikan atau tidak terdapat pengaruh terhadap probabilitas sehat atau tidak sehatnya bank di Indonesia untuk periode tahun 2005-2006.

Beberapa penelitian lainnya terkait kegagalan perusahaan juga banyak dilakukan terhadap industri non perbankan. Liu dan Wang (2016) melakukan penelitian pada perusahaan yang telah terpublikasi pada China Stock-Exchange sejak 2003-2013 (tidak termasuk di tahun 2008) dengan menggunakan model Logistik. Selain itu, peneliti mengembangkan model special treatment untuk mengukur distress pada perusahaan yang terdaftar tersebut. Hasil penelitian menunjukkan bahwa titik cut-off yang optimal misalnya cut-off point yang tepat harus meminimalkan jumlah kesalahan tipe I dan kesalahan tipe II, dan model logistik yang diusulkan untuk prediksi kegagalan perusahaan menjelaskan bahwa sebagian besar akurasi dalam utang rasio (seperempat sebelum kegagalan) dan nilai ekonomi yang tidak disesuaikan (model berkisar dari dua kuartal ke kuartal keempat sebelum kegagalan) menjadi indeks optimal untuk mendeteksi kegagalan perusahaan di Cina.

\section{METODE PENELITIAN}

\subsection{Data Penelitian}

Penelitian prediksi kegagalan BPR/BPRS dengan menggunakan data CAR yang dihitung berdasarkan laporan keuangan publikasi secara triwulanan periode tahun 2013-2017. Jumlah BPR/BPRS yang dijadikan obyek penelitian adalah seluruh BPR/BPRS yang dilikuidasi sejak 2013 sampai dengan 2017 yang memiliki data publikasi CAR lengkap, untuk periode: (1) minimal satu tahun (4 laporan triwulanan) sebelum BPR/BPRS tersebut ditetapkan sebagai Bank Dalam Pengawasan Khusus (BDPK); dan (2) selama tiga sampai dengan enam bulan setelah BDPK. Penggunaan periode sebelum BDPK lebih panjang karena digunakan sebagai dasar dalam membuat forecasting untuk memprediksi CAR pada periode bank ditetapkan BDPK. Variabel CAR dipilih karena berdasarkan ketentuan PBI No.11/20/PBI/2009, PBI No. 13/6/PBI/2011, dan POJK No.19/POJK.03/2017, CAR merupakan salah satu rasio indikator suatu BPR/BPRS untuk dapat dikelompokkan sebagai pengawasan normal, pengawasan intensif, dan pengawasan khusus serta bank gagal.

\subsection{Alat Analisis}


Analisis prediksi kegagalan BPR/BPRS menggunakan model ARIMA (Autoregressive Integrated Moving Average) yang dikembangkan oleh Box dan Jenkins. Model ARIMA ini merupakan teknik peramalan yang hanya didasarkan pada perilaku data itu sendiri pada periode sebelumnya dan secara penuh mengabaikan masalah dependensi dari variabel lain dalam melakukan peramalannya. ARIMA sangat baik ketepatannya untuk peramalan jangka pendek, keunggulan model ARIMA lainnya adalah fleksibel dan dapat mewakili rentang yang lebar dari karakter deret waktu yang terjadi dalam jangka pendek, terdapat prosedur yang formal dalam pengujian kesesuaian model. Untuk peramalan jangka panjang, ketepatan peramalan model ARIMA kurang baik. Analisis sign test digunakan untuk menguji keandalan hasil forecasting model ARIMA dengan data aktualnya.

\subsection{Teknik Penelitian}

Tahapan penelitian yang dilakukan dengan menggunakan model ARIMA adalah sebagai berikut.

a. Melakukan pengumpulan data laporan keuangan bank triwulanan khususnya data CAR yang telah dipublikasikan pada website resmi OJK selama periode tahun 2013-2017 untuk seluruh BPR/BPRS yang dilikuidasi. Jumlah data CAR yang digunakan sebagai dasar analisis adalah minimal empat triwulan sebelum bank ditetapkan sebagai BDPK.

b. Melakukan pengumpulan data CAR bulanan untuk seluruh BPR/BPRS yang dilikuidasi, untuk periode 3 s.d 6 bulan setelah bank ditetapkan BDPK. Data CAR bank diperoleh dari data yang tersedia di LPS.

c. Menerapkan prosedur Box-Jenkins (ARIMA) melalui beberapa tahapan, yaitu identifikasi, estimasi, dan evaluasi model serta peramalan. Hasil prediksi dengan model terbaik diuji dengan nilai aktualnya dengan menggunakan uji tanda untuk mengetahui apakah terdapat perbedaan secara nyata antara hasil prediksi dengan nilai aktualnya.

$A R: Y_{t}=\beta 0+\beta_{1} Y_{t-1}+\beta_{2} Y_{t-2}+\ldots+\beta_{p} Y_{t-p}+e_{t}$

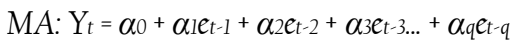

ARMA: $Y_{t}=\beta_{0}+\beta_{1} Y_{t-1}+\beta_{2} Y_{t-2}+\ldots+\beta_{p} Y_{t-p}+\alpha_{0}+\alpha_{1 l_{t-1}}+\alpha_{22 t-2}+\alpha_{3 l t-3 . .}+\alpha_{q} e_{t-q}$

dimana:

$\mathrm{Y} \quad=$ variabel dependen (CAR)

Ytp $\quad=\operatorname{lag}$ dari $Y$

et-q $\quad=\operatorname{lag}$ dari residual

$p \quad=$ tingkat $\mathrm{AR}$

q $\quad=$ tingkat $\mathrm{MA}$

d. Menetapkan Model Terbaik

Menentapkan model terbaik dilakukan dengan beberapa pendekatan diantaranya adalah:

a. Model terbaik dilihat dari banyaknya ordo yang signifikan pada model $\operatorname{ARIMA}(\mathrm{p}, \mathrm{d}, \mathrm{q})$. Penetapan dilakukan dengan proses trial and error melalui kombinasi ordo yang sederhana sampai diperoleh kombinasi ordo terbaik.

b. Uji model terbaik ARIMA $(\mathrm{p}, \mathrm{d}, \mathrm{q})$ yang menunjukkan bahwa model sudah fit dengan uji Box-Pierce (Ljung-Box). Hipotesis uji fit model yaitu:

HO : Model fit

$\mathrm{Hl}$ : Model tidak fit

Jika hasil uji menunjukkan nilai probabilitas lebih besar dari alpha 5\% maka hal ini berarti model fit. Selain uji fit model, model ARIMA(p,d,q) harus memiliki nilai Sum Square Error (SSE) dan Mean Square Error (MSE) terendah.

c. Jika pola atau plot data membentuk pola tren maka pendekatan model terbaik adalah dengan model analisis tren. Penentuan model tren terbaik dengan membandingkan Mean Absolute Percentage Error (MAPE), Mean Square Deviation (MSD) terendah. 
e. Nilai peramalan disediakan dalam output komputer dengan menggunakan aplikasi Eviews. Model ARIMA dibangun berdasarkan dua batasan yaitu (l) peramalan bersifat linier untuk observasi yang diamati; dan (2) seleksi model didasarkan pada prinsip parsimonious. Artinya model yang dipilih adalah model parameter yang paling efisien yaitu jumlah parameter sesedikit mungkin.

f. Selanjutnya, nilai CAR aktual dianalisis apakah masuk dalam selang pendugaan forecasting atau tidak. Dengan menggunakan sign test dapat diuji apakah hasil forecasting CAR secara tepat mampu memprediksi CAR aktual pada saat ditetapkan sebagai bank BDPK.

\section{HASIL ANALISIS DAN PEMBAHASAN}

Pada awalnya jumlah BPR/BPRS yang menjadi obyek penelitian adalah sebanyak 84 BPR/BPRS, yaitu BPR/BPRS yang gagal sejak 2006 sampai dengan 2017. Namun, oleh karena data yang tersedia yaitu data CAR yang diambil dari laporan keuangan BPR/BPRS yang dipublikasikan melalui website OJK tidak semuanya lengkap, maka jumlah BPR/BPRS yang menjadi sampel sebanyak 40 BPR/BPRS. Hasil dari peramalan ini berikutnya akan dibandingkan dengan data CAR post-test (CAR actual) yang tersedia dalam sistem informasi di LPS. LPS memperoleh CAR bank yang ditetapkan dalam BDPK dari penyampaian OJK kepada LPS secara bulanan.

Analisis forecasting dilakukan dengan menggunakan model ARIMA (Autoregressive Integrated Moving Average). Langkah yang dilakukan adalah (l) menyiapkan data CAR secara time series setiap BPR/BPRS yang menjadi sampel. Data CAR diambil untuk posisi per triwulanan antara satu hingga lima tahun sebelum bank ditetapkan dalam BDPK; (2) membuat forecasting data CAR pada saat ditetapkan BDPK dan periode berikutnya sesuai dengan data CAR aktual yang tersedia, dengan menggunakan ARIMA; (3) membandingkan antara data CAR aktual dengan CAR dalam selang pendugaan; (4) melakukan uji signifikansi perbedaannya dengan menggunakan Sign Test.

Pada umumnya penetapan BPR/BPRS sebagai BDPK oleh OJK dilakukan setelah koreksi angka CAR yang dilakukan berdasarkan hasil pemeriksaan kualitas aktiva produktif. Akibatnya, pada umumnya terdapat keterlambatan penetapan status BDPK yaitu setelah bank mengalami penurunan CAR yang tajam hingga CAR negatif. Oleh karena itu, untuk menghilangkan bias data CAR, penulis melakukan penyesuaian terhadap data CAR pada saat ditetapkan BDPK, yaitu menggunakan data CAR saat terjadi penurunan secara signifikan dari periode sebelumnya. Hasil model forecasting terbaik berupa ARIMA (p,d,q) sebagaimana disajikan pada Lampiran.

Berdasarkan data yang disajikan dalam Lampiran diketahui bahwa terdapat 31 BPR/BPRS yang memiliki model forecasting terbaik yaitu ARIMA(p,d,q). Hasil uji fit model menunjukkan nilai probabilitas yang lebih besar dari alpha 5\% artinya model sudah fit. Adapun model yang tidak mengeluarkan nilai uji fit model, menghasilkan error terendah yaitu SSE dan MSE terendah. Sebanyak 9 BPR/BPRS karena memiliki data yang sangat terbatas maka pendekatan model forecasting yang paling sederhana dan terbaik melalui trend analysis, pemilihan model terbaik didasarkan atas bentuk tren dan MAPE, MAD, MSD yang terendah.

Model terbaik ini yang menjadi dasar untuk menganalisis peramalan CAR kedepan yaitu pada saat BPR/BPRS ditetapkan BDPK dan untuk periode selanjutnya. Untuk mengetahui apakah model mampu memprediksi CAR dengan akurat maka akan dilihat apakah CAR aktual masuk kedalam selang pendugaan peramalan. Jika hasil data aktual masuk dalam selang peramalan CAR maka dapat disimpulkan bahwa data CAR dapat digunakan untuk memprediksi nilai CAR dimasa yang akan datang. Selanjutnya, data CAR aktual akan dicocokkan dan dianalisis secara statistik, apakah dengan menggunakan model forecasting yang terbaik, data CAR bisa digunakan untuk memprediksi nilai CAR ke depan. 
Hasil peramalan dari model terbaik terhadap angka CAR untuk beberapa periode kedepan akan dibandingkan dengan angka CAR aktual. Hal ini dilakukan untuk mengetahui/menguji efektivitas model peramalan dengan statistika apakah mampu memprediksi nilai CAR dengan tepat. Tabel 3 menyajikan perbandingan antara data CAR forecasting dan data CAR aktual masing-masing BPR/BPRS untuk periode sebelum bank ditetapkan dalam status BDPK. Dengan alasan kerahasiaan, daftar nama BPR/BPRS sengaja diganti dengan kode bank. Keterangan pada kode ketepatan dengan angka 0 dan l, diberi angka 1 jika hasil peramalan sesuai dengan data aktual artinya data aktual masuk dalam Selang Kepercayaan (SK) peramalan 95\% sedangkan angka 0 diberikan jika hasil peramalan dengan selang kepercayaan tidak sesuai dengan data aktual.

TABEL 3: Perbandingan CAR forecasting dengan CAR aktual

\begin{tabular}{|c|c|c|c|c|c|}
\hline \multirow{2}{*}{ Bank } & \multirow[b]{2}{*}{ Actual } & \multirow[b]{2}{*}{ Forecast } & \multicolumn{2}{|c|}{ SK 95\% } & \multirow{2}{*}{ Keterangan } \\
\hline & & & Lower & Upper & \\
\hline \multirow{4}{*}{ BPR Xl } & -21.00 & 124.26 & 76.11 & 172.41 & \multirow{4}{*}{0} \\
\hline & -35.00 & 220.19 & 143.69 & 296.69 & \\
\hline & -19.71 & 162.17 & 21.07 & 303.26 & \\
\hline & -30.98 & 229.26 & 71.03 & 387.48 & \\
\hline \multirow{3}{*}{ BPR X2 } & -59.00 & -29.54 & -42.42 & -16.66 & \multirow{3}{*}{0} \\
\hline & -42.58 & -13.30 & -27.03 & 0.42 & \\
\hline & -96.44 & -5.36 & -25.59 & 14.87 & \\
\hline BPR X3 & -10.02 & 6.32 & -11.18 & 23.83 & 1 \\
\hline \multirow{2}{*}{ BPR X4 } & -16.78 & 6.10 & - & - & \multirow{2}{*}{0} \\
\hline & -31.64 & 5.98 & - & - & \\
\hline \multirow{2}{*}{ BPR X5 } & -22.00 & 7.81 & 0.59 & 15.03 & \multirow{2}{*}{0} \\
\hline & -19.76 & 15.47 & 8.16 & 22.79 & \\
\hline \multirow{3}{*}{ BPR X6 } & -537.00 & -186.31 & -308.56 & -64.06 & \multirow{3}{*}{1} \\
\hline & -179.67 & 28.91 & -133.60 & 191.41 & \\
\hline & -208.16 & -128.30 & -299.42 & 42.82 & \\
\hline \multirow{4}{*}{ BPR X7 } & -11.00 & -18.53 & -34.70 & -2.36 & \multirow{4}{*}{1} \\
\hline & -22.00 & -7.70 & -31.01 & 15.61 & \\
\hline & -42.00 & -18.92 & -42.38 & 4.55 & \\
\hline & -96.09 & -17.12 & -42.19 & 7.94 & \\
\hline BPR X8 & -10.16 & 11.14 & -0.98 & 23.26 & 0 \\
\hline BPR X9 & -33.82 & 29.66 & 11.37 & 47.95 & 0 \\
\hline \multirow{2}{*}{ BPR X10 } & -19.74 & 10.28 & 1.22 & 19.34 & \multirow{2}{*}{0} \\
\hline & -29.87 & 18.58 & 3.88 & 33.28 & \\
\hline \multirow{3}{*}{ BPR XIl } & -14.81 & -13.56 & - & - & \multirow{3}{*}{1} \\
\hline & -25.00 & -48.32 & - & - & \\
\hline & -464.87 & -99.42 & - & - & \\
\hline \multirow{2}{*}{ BPR X12 } & -53.93 & 9.93 & 1.56 & 18.31 & \multirow{2}{*}{0} \\
\hline & -83.77 & 10.54 & -2.17 & 23.26 & \\
\hline BPR XI3 & -11.00 & -16.39 & -197.24 & 164.46 & 1 \\
\hline BPR XI4 & -45.69 & 99.60 & -373.67 & 572.87 & 1 \\
\hline
\end{tabular}




\begin{tabular}{|c|c|c|c|c|c|}
\hline \multirow{2}{*}{ Bank } & \multirow[b]{2}{*}{ Actual } & \multirow[b]{2}{*}{ Forecast } & \multicolumn{2}{|c|}{ SK 95\% } & \multirow{2}{*}{ Keterangan } \\
\hline & & & Lower & Upper & \\
\hline BPR X15 & -147.80 & -119.59 & - & - & 1 \\
\hline \multirow{4}{*}{ BPR X16 } & -24.00 & 12.53 & - & - & \multirow{4}{*}{0} \\
\hline & -51.00 & 13.74 & - & - & \\
\hline & -173.00 & 15.27 & - & - & \\
\hline & -187.38 & 17.12 & - & - & \\
\hline BPR X17 & -233.52 & 30.62 & - & - & 0 \\
\hline BPR X18 & -14.97 & 7.57 & 1.70 & 13.45 & 0 \\
\hline \multirow{3}{*}{ BPR X19 } & -16.00 & 1.89 & -14.64 & 18.41 & \multirow{3}{*}{1} \\
\hline & 0.01 & 8.16 & -14.74 & 31.06 & \\
\hline & -16.46 & 1.28 & -28.87 & 31.44 & \\
\hline BPR X20 & 0.01 & 192.50 & & & 0 \\
\hline BPR X21 & -117.55 & 36.05 & 5.52 & 66.59 & 0 \\
\hline BPR X22 & -124.30 & 16.52 & -6.21 & 39.25 & 0 \\
\hline \multirow{2}{*}{ BPR X23 } & 0.71 & 8.74 & -23.01 & 40.49 & \multirow{2}{*}{0} \\
\hline & -80.09 & 24.70 & -7.07 & 56.46 & \\
\hline BPR X24 & -16.04 & -1.77 & - & - & 0 \\
\hline \multirow{2}{*}{ BPR X25 } & -43.74 & 0.00 & - & - & \multirow{2}{*}{0} \\
\hline & -50.80 & 0.00 & - & - & \\
\hline \multirow{3}{*}{ BPR X26 } & -43.00 & -9.74 & -16.77 & -2.72 & \multirow{3}{*}{0} \\
\hline & -51.00 & -11.23 & -19.34 & -3.11 & \\
\hline & -58.00 & -11.77 & -20.76 & -2.79 & \\
\hline \multirow{2}{*}{ BPR X27 } & -48.29 & 2.20 & - & - & \multirow{2}{*}{0} \\
\hline & -69.09 & -12.62 & - & - & \\
\hline \multirow{3}{*}{ BPR X28 } & -13.00 & 15.40 & 12.44 & 18.36 & \multirow{3}{*}{0} \\
\hline & -18.00 & 9.24 & 3.54 & 14.95 & \\
\hline & -22.83 & 11.00 & 5.13 & 16.87 & \\
\hline \multirow{3}{*}{ BPR X29 } & -9.00 & 14.48 & 12.59 & 16.38 & \multirow{3}{*}{0} \\
\hline & -108.00 & 14.21 & 12.31 & 16.11 & \\
\hline & -261.21 & 14.24 & 12.08 & 16.41 & \\
\hline \multirow{4}{*}{ BPR X30 } & -41.00 & 17.02 & 2.95 & 31.09 & \multirow{4}{*}{0} \\
\hline & -62.00 & 21.50 & 7.39 & 35.62 & \\
\hline & -90.00 & 22.82 & 6.38 & 39.26 & \\
\hline & -126.61 & 21.32 & 1.45 & 41.19 & \\
\hline \multirow{3}{*}{ BPR X31 } & -207.00 & 14.33 & 12.53 & 16.12 & \multirow{3}{*}{0} \\
\hline & -266.00 & 14.57 & 12.77 & 16.36 & \\
\hline & -325.53 & 14.80 & 13.01 & 16.60 & \\
\hline & -57.00 & 21.03 & 2.54 & 39.52 & \\
\hline BPR X32 & -78.00 & 13.75 & -10.35 & 37.84 & 0 \\
\hline & -146.34 & 19.28 & -6.30 & 44.86 & \\
\hline BPR X33 & -54.00 & 14.34 & 8.84 & 19.85 & 0 \\
\hline
\end{tabular}




\begin{tabular}{|c|c|c|c|c|c|}
\hline \multirow{3}{*}{ Bank } & \multirow[b]{2}{*}{ Actual } & \multirow[b]{2}{*}{ Forecast } & \multicolumn{2}{|c|}{ SK 95\% } & \multirow{2}{*}{ Keterangan } \\
\hline & & & Lower & Upper & \\
\hline & -72.00 & 14.62 & 7.74 & 21.50 & \\
\hline \multirow{3}{*}{ BPR X34 } & -19.00 & 18.89 & 12.89 & 24.89 & \multirow{3}{*}{0} \\
\hline & -25.00 & 21.58 & 15.06 & 28.11 & \\
\hline & -31.94 & 22.95 & 16.38 & 29.53 & \\
\hline \multirow{2}{*}{ BPR X35 } & -159.00 & 17.95 & 12.31 & 23.59 & \multirow{2}{*}{0} \\
\hline & -261.00 & 18.83 & 12.74 & 24.92 & \\
\hline \multirow{3}{*}{ BPR X36 } & -3.00 & 4.42 & -5.17 & 14.02 & \multirow{3}{*}{0} \\
\hline & -19.00 & 5.49 & -4.18 & 15.16 & \\
\hline & -18.56 & 3.39 & -8.53 & 15.32 & \\
\hline \multirow{2}{*}{ BPR X37 } & -45.75 & 16.45 & -0.71 & 33.60 & \multirow{2}{*}{0} \\
\hline & -89.52 & -26.91 & -44.36 & -9.46 & \\
\hline \multirow{2}{*}{ BPR X38 } & -19.26 & 349.12 & 273.81 & 424.43 & \multirow{2}{*}{0} \\
\hline & -173.72 & 559.62 & 387.27 & 731.97 & \\
\hline \multirow{2}{*}{ BPR X39 } & -284.00 & 1.57 & -6.96 & 10.09 & \multirow{2}{*}{0} \\
\hline & -245.39 & 1.13 & -7.42 & 9.67 & \\
\hline \multirow{3}{*}{ BPR X40 } & -5.35 & 12.79 & 10.42 & 15.15 & \multirow{3}{*}{0} \\
\hline & -63.00 & 12.15 & 9.36 & 14.94 & \\
\hline & -63.74 & 11.18 & 8.11 & 14.25 & \\
\hline \multicolumn{5}{|c|}{ Persentase ketepatan } & $20 \%$ \\
\hline
\end{tabular}

Sumber: data olah forecasting dan data internal LPS, diolah (2019)

Berdasarkan TABEL 3 tersebut, total ada 31 BPR/BPRS yang memiliki model forecasting terbaik yaitu ARIMA(p,d,q). Hasil uji fit model menunjukkan nilai probabilitas yang lebih besar dari alpha 5\% artinya model sudah fit. Adapun model yang tidak mengeluarkan nilai uji fit model, menghasilkan error terendah yaitu SS dan MS terendah. Sebanyak 9 BPR/BPRS karena memiliki data yang sangat terbatas maka pendekatan model forecasting yang paling sederhana dan terbaik melalui trend analysis, pemilihan model terbaik didasarkan atas bentuk tren dan MAPE, MAD, MSD yang terendah. Berikut adalah 9 BPR/BPRS yang memiliki model forecasting dengan tren analysis.

TABEL 4: Model forecasting terbaik-analisis tren

\begin{tabular}{lllllll} 
No & Bank & $\begin{array}{l}\text { Model } \\
\text { Tren }\end{array}$ & Persamaan & MAPE & MAD & MSD \\
1 & BPR X4 & Linier & Yt $=6,460-0,12 \times t$ & 0,0 & 0,0 & 0,0 \\
\hline 2 & BPR X11 & Kuadratik & $Y \mathrm{t}=-37,920+38,8 \times \mathrm{t}-8,2 \times \mathrm{t}^{\wedge} 2$ & 0,0 & 0,0 & 0,0 \\
\hline 3 & BPR X15 & Kuadratik & $\mathrm{Yt}=-47+101 \times \mathrm{t}-23,2 \times \mathrm{t}^{\wedge} 2$ & 153,7 & 25,1 & 785,6 \\
\hline 4 & BPR X16 & Kuadratik & $\mathrm{Yt}=17,915-2,129 \times \mathrm{t}+0,1591 \times \mathrm{t}^{\wedge} 2$ & 4,1 & 0,5 & 0,4 \\
\hline 5 & BPR X17 & Kuadratik & $\mathrm{Yt}=32,49-39,77 \times \mathrm{t}+7,88 \times \mathrm{t}^{\wedge} 2$ & 1626,2 & 1,1 & 1,5 \\
\hline 6 & BPR X20 & Kuadratik & $\mathrm{Yt}=51,3+2,56 \times \mathrm{t}+0,457 \times \mathrm{t}^{\wedge} 2$ & 8,4 & 13,4 & 50,7 \\
\hline 7 & BPR X24 & Linier & $\mathrm{Yt}=10,96-2,122 \times \mathrm{t}$ & 358,3 & 1,2 & 1,7 \\
\hline 8 & BPR X25 & Kuadratik & $\mathrm{Yt}=20,4+9,6 \times \mathrm{t}-2,94 \times \mathrm{t}^{\wedge} 2$ & 21785,0 & 5,9 & 45,2 \\
\hline 9 & BPR X27 & Kuadratik & $\mathrm{Yt}=14,280+6,4 \times \mathrm{t}-2,4 \times \mathrm{t}^{\wedge} 2$ & 0,0 & 0,0 & 0,0 \\
\hline
\end{tabular}

Sumber: Hasil olah data CAR forecasting, (2018)

Hasil peramalan dari model terbaik terhadap CAR untuk beberapa periode kedepan akan dibandingkan dengan nilai CAR aktual. Hal ini dilakukan untuk mengetahui/menguji efektivitas model peramalan dengan statistika apakah mampu memprediksi nilai CAR dengan 
tepat, atau presentasi ketepatan peramalan. Selanjutnya, data CAR forecasting diberi kode dengan angka 0 dan 1 . Diberi angka 1 jika hasil peramalan sesuai dengan data aktual artinya data aktual masuk dalam Selang Kepercayaan (SK) peramalan 95\% sedangkan angka 0 diberikan jika hasil peramalan dengan selang kepercayaan tidak sesuai dengan data aktual. Untuk dapat menyimpulkan apakah data CAR forecasting berbeda secara nyata dengan CAR aktual, dengan hipotesis sebagai berikut:

Ho: Hasil peramalan CAR secara tepat mampu memprediksi CAR aktual $(\mu=1)$.

Hı: Hasil peramalan CAR tidak mampu memprediksi CAR aktual dengan tepat $(\mu<1)$.

Oleh karena data bersifat kategorikal, maka pengujian signifikansi perbedaan menggunakan statistik nonparametrik yaitu sign test satu sampel. Dengan metode sign test menggunakan alat bantu SPSS menghasilkan sebagaimana tercantum pada Tabel 4.

TABEL 5: Hasil Uji Tanda

\begin{tabular}{lrrrr}
\hline Null hypothesis & \multicolumn{2}{c}{$\mathrm{H}_{0}: \eta=1$} \\
Alternative hypothesis & $\mathrm{H}_{1}: \eta<1$ \\
Sample & Number $<1$ & Number $=1$ & Number $>1$ & P-Value \\
\hline Bank & 32 & 8 & 0 & 0,000 \\
\hline
\end{tabular}

Berdasarkan TABEL 5 tersebut diketahui bahwa nilai signifikansi Asymp.Sig (2-tailed) sebesar 0,000 lebih kecil dari 0,05. Dengan menggunakan angka probabilitas pada kolom ASYMP.SIG yatu 0,000 jauh di bawah 0,05 maka H0 ditolak. Hasil pengujian ini menyimpulkan bahwa CAR yang dihitung berdasarkan laporan keuangan tidak dapat digunakan untuk memprediksi BPR/BPRS menjadi bank bermasalah yang selanjutnya menjadi bank gagal.

Hasil penelitian membuktikan bahwa laporan keuangan BPR/BPRS tidak akurat untuk memprediksi kegagalan bank. Hal ini disebabkan seluruh kegagalan BPR/BPRS terjadi karena penyimpangan (fraud) yang dilakukan baik oleh pemegang saham, pengurus, maupun karyawan bank. Laporan keuangan yang ada tidak merepresentasikan adanya fraud tersebut sampai dengan lembaga pengawas perbankan (BI/OJK) melakukan pemeriksaan dan menemukan adanya fraud tersebut. Selama fraud tersebut belum ditemukan maka laporan keuangan menyajikan informasi keuangan yang tidak menggambarkan kondisi keuangan sesungguhnya (misleading). Dengan demikian, analisis apapun termasuk perhitungan CAR yang didasarkan atas laporan keuangan tersebut akan menjadi bias dan cenderung menyesatkan. Meskipun fraud yang terjadi segera ditemukan oleh BI/OJK, maka hal inipun tetap menjadi masalah karena kerugian akibat dari fraud tersebut telah terjadi.

Hasil penelitian ini sejalan denga hasil kajian LPS (2017) bahwa hanya 35\% aset dalam neraca unaudited BPR/BPRS yang dicabut izin usahanya yang memenuhi prinsip pengakuan dan penilaian aset berdasarkan standar akuntansi keuangan yang berlaku. Dalam kondisi neraca yang hanya 35\% aset yang memenuhi standar akuntansi keuangan maka sangat sulit untuk mendapatkan hasil analisis yang andal. Salah satu penyebab terjadinya kondisi demikian adalah tidak diwajibkannya seluruh BPR/BPRS untuk dilakukan audit atas laporan keuangannya oleh akuntan publik.

Saat ini terdapat Pengaturan BI No. 15/3/PBI/2013 tentang Transparansi Kondisi Keuangan BPR bahwa kewajiban laporan keuangan untuk diaudit oleh akuntan publik hanya terhadap BPR yang mempunyai total aset lebih besar dari atau sama dengan Rpl0.000.000.000,00 (sepuluh miliar rupiah). Sementara bagi BPR yang mempunyai total aset lebih kecil dari Rp10.000.000.000,00 (sepuluh miliar rupiah), laporan keuangan yang disampaikan kepada BI (saat ini OJK) adalah laporan keuangan tahunan yang telah dipertanggungjawabkan dalam Rapat Umum Pemegang Saham. Hal ini berarti bagi BPR yang memiliki total aset lebih kecil 
dari Rp10.000.000.000,00 (sepuluh miliar rupiah) dapat tidak dilakukan audit oleh akuntan publik.

Temuan penelitian ini juga sejalan dengan hasil penelitian yang dilakukan oleh:

1. Wilopo (2001) yang menyimpulkan bahwa kegagalan bank di Indonesia tidak dapat diprediksi dengan sempurna apabila hanya menggunakan model CAMELS.

2. Aryati dan Balafif (2007) yang menyimpulkan antara lain bahwa CAR, ROA, ROE, LDR, dan NIM menunjukkan hasil yang tidak signifikan atau tidak terdapat pengaruh terhadap probabilitas sehat atau tidak sehatnya bank di Indonesia.

3. Jones (2017) yang menyimpulkan bahwa variabel non tradisional seperti struktur kepemilikan/konsentrasi dan kompensasi CEO adalah salah satu prediktor terkuat dalam memprediksi kegagalan perusahaan.

4. Marcelinda, Paramu, dan Puspitasari (2014) yang menyimpulkan bahwa model Altman ZScore memiliki tingkat akurasi yang rendah dalam memprediksi tingkat kebangkrutan bank.

Namun demikian, terdapat beberapa hasil penelitian lain yang secara tidak langsung tidak sejalan dengan hasil penelitian ini. Almilia dan Kristijadi (2003) menyimpulkan bahwa rasio keuangan yang paling dominan dalam menentukan financial distress adalah rasio profit margin, rasio financial leverage, rasio likuiditas, dan rasio pertumbuhan. Hal ini berarti analisis rasio keuangan masih memiliki tingkat keandalan dalam memprediksi kegagalan perusahaan. Namun penelitian Almilia dan Kristijadi (2003) ini menggunakan sampel perusahaan manufaktur (bukan bank) yang terdaftar di Bursa Efek Jakarta. Selain itu, Nugroho (2012) menyimpulkan hasil penelitiannya bahwa dengan menggunakan rasio keuangan (CAR, LDR, NPL, BOPO, ROA, ROE, dan NIM) menunjukkan kebangkrutan bank mencapai 94,5\% dengan variabel LDR secara signifikan memengaruhi probabilitas kebangkrutan dibandingkan dengan variabel lainnya. Penelitian Nugroho (2012) menggunakan sampel 130 bank umum (bukan BPR/BPRS) periode tahun 2006. Oleh karena itu, hasil penelitian Almilia dan Kristijadi (2003) dan Nugroho (2012) tidak dapat dikatakan bertentangan dengan hasil penelitian karena memiliki objek penelitian yang berbeda.

Selain itu, hasil penelitian ini juga tidak sejalan dengan hasil penelitian yang dilakukan oleh Wang, Jiang, dan Zhen-Jia-Liu (2016) yang menyimpulkan bahwa rasio kecukupan modal efektif dalam memprediksi kegagalan bank di negara-negara NAFTA, ASEAN, UE, NIC, dan G20. Perbedaan hasil penelitian ini disebabkan oleh berbedanya obyek penelitian. Penelitian yang dilakukan oleh Wang, Jiang, dan Zhen-Jia-Liu (2016) menggunakan bank umum sebagai obyek penelitian, sementara dalam penelitian ini menggunakan BPR/BPRS sebagai obyek.

\section{KESIMPULAN DAN REKOMENDASI}

\subsection{Kesimpulan}

Berdasarkan hasil penelitian ini, dapat disimpulkan bahwa CAR forecasting berdasarkan CAR sebelum BPR/BPRS berstatus BDPK dengan menggunakan metode ARIMA dan Sign Test diketahui bahwa terdapat perbedaan secara nyata dengan angka CAR actual. Hal ini berarti, CAR bank yang dihitung berdasarkan laporan keuangan publikasi BPR/BPRS triwulanan tidak akurat untuk memprediksi BPR/BPRS akan berstatus BDPK karena turunnya angka CAR yang signifikan.

Kondisi demikian dapat terjadi karena kegagalan BPR/BPRS di Indonesia pada umumnya diakibatkan adanya penyimpangan (fraud) baik yang dilakukan oleh pemilik, pengurus 
maupun karyawan bank. Sebelum penyimpangan ditemukan dalam pemeriksaan OJK, laporan keuangan tidak dapat menggambarkan kondisi keuangan yang sebenarnya. Oleh karena itu, rasio keuangan yang dihitung berdasarkan laporan keuangan tersebut antara lain besaran angka CAR juga tidak dapat menggambarkan kondisi yang sebenarnya (mislead). Kondisi ini memperkuat kesimpulan bahwa CAR BPR/BPRS tidak akurat untuk memprediksi kegagalan bank tersebut.

\subsection{Rekomendasi}

Berdasarkan hasil penelitian ini, kami menyarankan sebagai berikut:

a. Peningkatan pengawasan oleh OJK dengan lebih difokuskan pada implementasi tata kelola bank yang baik (Good Corporate Governance) sehingga dapat mencegah terjadinya fraud atau setidak-tidaknya dapat segera ditemukan apabila terjadi fraud.

b. Menghilangkan pengecualian bagi BPR/BPRS untuk tidak dilakukan audit laporan keuangan oleh akuntan publik.

c. Selama belum ada perubahan kebijakan dari otoritas perbankan dalam rangka memperbaiki tata kelola BPR/BPRS, LPS sebaiknya menggunakan informasi mengenai implementasi tata kelola bank (Good Corporate Governance) dalam rangka membuat early warning terhadap probabilitas kegagalan BPR/BPRS. Analisis berdasarkan laporan keuangan digunakan sebagai pelengkap untuk mengkonfirmasi hasil analisis implementasi tata kelola BPR/BPRS yang bersangkutan

\section{UCAPAN TERIMA KASIH}

Penulis ingin menyampaikan ucapan terima kasih dan penghargaan setingi-tingginya kepada semua pihak yang membantu penulis dalam menyelesaikan penelitian ini sebagai salah satu syarat untuk menyelesaikan program doktoral di Institut Pertanian Bogor. Terkhusus ucapan terima kasih penulis sampaikan kepada pimpinan LPS yang memberikan beasiswa kepada penulis untuk melanjutkan studi pada program doktoral ini. Selain itu, penulis juga ingin menyampaikan ucapan terima kasih kepada reviewer yang memberikan banyak masukan untuk peningkatan kualitas paper ini.

\section{DAFTAR PUSTAKA}

Aryati T \& Balafif S. (2007). Analisis Faktor yang Mempengaruhi Tingkat Kesehatan Bank dengan Regresi Logit. Journal The WINNERS 8(2), 111-125.

Bani M, Zadehbagher M, Saberimanesh JJMA. (2014). Prediction of bank failures based on Zmisky and Toffler models in the banking industry or Iran. Kuwait Chapter of the Arabian Journal of Business and Management Review, 3(12), 142-152.

Bank Indonesia. (1997). Surat Keputusan DIreksi Bank Indonesia No. 30/12/KEP/DIR tentang Penilaian Tingkat Kesehatan Bank Umum. Retrieved from https://www.ojk.go.id/Files/batchen2/20.pdf

Bank Indonesia. (2007). Peraturan Bank Indonesia Nomor No.9/17/PBI/2007 tentang Penilaian Tingkat Kesehatan Bank Umum. Retrieved from https:/www.ojk.go.id/Files/batchen2/20.pdf

Bank Indonesia. (2013). Peraturan Bank Indonesia Nomor No.13/1/PBI/2011 tentang Penilaian Tingkat Kesehatan Bank Umum. Retrieved from https:/www.ojk.go.id/Files/batchen2/20.pdf

Bashir A, Javed A, Iqbal S. (2015). Business failures prediction Karachi stick exchange. Indian Journal of Management Science, 5(1), 74-82.

Calabrese R, Guidici P. (2015). Estimating bank default with generalised extreme value regression models. The Journal of The Operational Research Society, 66(11), 1783-1792.

Cole RA, White LJ. (2012). Déjà vu all over again: the causes of U.S. commercial bank failures this time around. Journal of Financial Service Research, 421(2), 5-29. 
Ekinci A, Erdal HI. (2016). Forecasting bank failure: base learners, ensembles and hybrid ensembles. Computational Economics, 49(4), 677-686.

Hadad DM, Santoso W, Besar DS, Rulina I. (2004). Probabilitas kegagalan korporasi dengan menggunakan model merton. Jakarta: Bank Indonesia.

Konstituanto, A. (2012). Probabilitas Kegagalan Bank dari Aspek Manajemen dan Keuangan. Bogor: Institut Pertanian Bogor.

Liu ZJ, Wang YS. (2016). Corporate failure prediction models for advanced research in China: identifying the optimal cut off point. Asian Economic and Financial Review, 6(1), 54-65.

Merton RC. (1974). On the pricing of corporate debt: The risk structure of interest rates. The Journal of Finance, 29(2).

Ohlson, J. A. (1980). Financial Ratios and The Probabilistic Prediction of Bankcruptcy. Journal of Accounting Research, 18, 109-131.

Ooghe H, Spaenjers C, Vandermoere P. (2009). Business failure prediction: simple-intuitive models versus statistical model. IUP Journal of Business Strategy, 6(4), 7-44.

Otoritas Jasa Keuangan. (2017). Peraturan Otoritas Jasa Keuangan Nomor 19/POJK.03/2017. Retrieved from https://www.ojk.go.id/id/kanal/perbankan/regulasi/peraturanojk/Documents/Pages/POJK-tentang-Penetapan-Status-dan-Tindak-LanjutPengawasan-Bank-Perkreditan-Rakyat-dan-Bank-Pembiayaan-RakyatSyariah/SAL\%20POJK\%2019\%20-\%20Exit\%20Policy\%20BPR\%BPRS.pdf

Outtecheva, N. (2007). Corporate Financial Distress: An Empirical Analysis of Distress Risk. Swiss: University of St.Gallen.

Ozili PK. (2017). Bank earnings management and income smoothing using commission and fee income. International Journal of Managerial Finance, 13(4), 419-439.

Pranowo, K., Achsani, N. A., Manurung, A. H., \& Nuryantono, N. (2010). Determinant of Corporate Financial Distress in an Emerging Market Economy: Empirical Evidence from the Indonesian Stock Exchange 2004-2008. International Research Journal of Finance and Economics. Issue 52, 80-88.

Singh, K., \& Singh, P. (2014). Early warning signals of merger of banks- a case study of global trust bank (GTB) and centurion bank of Punjabi (CBOP) in India. International Journal of Financial Management. 4(4), 49-55.

Thomson, J. B. (1991). Predicting bank failures in 1980s. Economic Review, 27(1), 9-20.

Tudel M, Garry Y. (2004). A Merton-Model approach to assessing the default risk of UK public companies. Bank of England Working Paper Series No. 194.

Whitaker, R. (1999). The Early Stages of Financial Distress. Journal of Economics and Finance. 23(2), $123-132$.

Wibowo, B. (2017). Metode Pengukuran Probabilitas Kebangkrutan Bank dan Analisis Hubungannya Dengan Diversifikasi Sumber Pendapatan: Kasus Perbankan Indonesia. Jurnal Manajemen, Strategi Bisnis dan Kewirausahaan. 11(l), 52-66.

Wilopo. (2006). Analisis Faktor-Faktor yang Mempengaruhi Kecenderungan Kecurangan Akuntansi. Simposium Nasional Akuntansi $X$.

Wruck, K. H. (1990). Financial Distress, Reorganization, and Organizational Efficiency. Journal of Financial Economics. 27(2), 419-444.

\section{LAMPIRAN}

Hasil Model Forecasting ARIMA(p,d,q) Terbaik

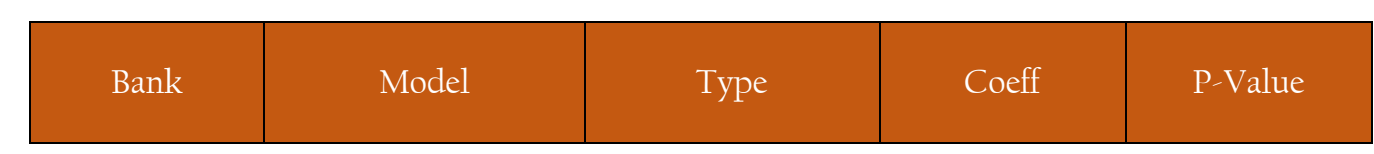




\begin{tabular}{|c|c|c|c|c|}
\hline Bank & Model & Type & Coeff & P-Value \\
\hline \multirow{5}{*}{ BPRS Xl } & \multirow{5}{*}{$\operatorname{ARIMA}(2,1,2)$} & AR 1 & $-0,798$ & 0,155 \\
\hline & & AR 2 & 0,022 & 0,981 \\
\hline & & MA 1 & $-1,033$ & 0,001 \\
\hline & & MA 2 & $-1,393$ & 0,066 \\
\hline & & Constant & 186,808 & 0,000 \\
\hline \multirow{5}{*}{ BPRS X2 } & \multirow{5}{*}{$\operatorname{ARIMA}(2,1,2)$} & AR 1 & $-0,676$ & 0,047 \\
\hline & & AR 2 & $-0,794$ & 0,095 \\
\hline & & MA 1 & $-0,044$ & 0,849 \\
\hline & & MA 2 & 1,155 & 0,000 \\
\hline & & Constant & $-532,33$ & 0,000 \\
\hline \multirow{6}{*}{ BPRS X3 } & \multirow{6}{*}{$\operatorname{ARIMA}(2,0,2)$} & AR 1 & $-0,545$ & 0,049 \\
\hline & & AR 2 & 0,457 & 0,306 \\
\hline & & MA 1 & $-0,9637$ & 0,000 \\
\hline & & MA 2 & 0,083 & 0,842 \\
\hline & & Constant & 7,32 & 0,024 \\
\hline & & Mean & 6,73 & 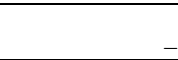 \\
\hline \multirow{5}{*}{ BPRS X5 } & \multirow{5}{*}{$\operatorname{ARIMA}(2,0,1)$} & AR 1 & 0,698 & 0,041 \\
\hline & & AR 2 & $-0,997$ & 0,008 \\
\hline & & MA 1 & 0,858 & 0,051 \\
\hline & & Constant & 8,030 & 0,000 \\
\hline & & Mean & 6,183 & 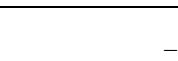 \\
\hline \multirow{3}{*}{ BPRS X6 } & \multirow{3}{*}{$\operatorname{ARIMA}(1,1,1)$} & AR 1 & $-0,701$ & 0,040 \\
\hline & & MA 1 & 1,175 & 0,001 \\
\hline & & Constant & $-641,065$ & 0,000 \\
\hline \multirow{3}{*}{ BPRS X7 } & \multirow{3}{*}{$\operatorname{ARIMA}(1,1,1)$} & AR 1 & $-0,590$ & 0,324 \\
\hline & & MA 1 & 1,448 & 0,087 \\
\hline & & Constant & $-482,813$ & 0,000 \\
\hline \multirow{5}{*}{ BPRS X8 } & \multirow{5}{*}{$\operatorname{ARIMA}(2,0,1)$} & AR 1 & 1,233 & 0,054 \\
\hline & & AR 2 & $-0,733$ & 0,312 \\
\hline & & MA 1 & 1,131 & 0,009 \\
\hline & & Constant & 51,712 & 0,000 \\
\hline & & Mean & 103,366 & 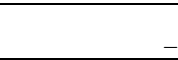 \\
\hline \multirow{5}{*}{ BPRS X9 } & \multirow{5}{*}{$\operatorname{ARIMA}(2,1,2)$} & AR 1 & 0,051 & 0,639 \\
\hline & & AR 2 & $-0,970$ & 0,000 \\
\hline & & MA 1 & 0,416 & 0,079 \\
\hline & & MA 2 & $-0,432$ & 0,076 \\
\hline & & Constant & 0,67 & 0,739 \\
\hline \multirow{3}{*}{ BPRS X10 } & \multirow{3}{*}{$\operatorname{ARIMA}(3,0,1)$} & AR 1 & $-0,213$ & 0,598 \\
\hline & & AR 2 & $-0,536$ & 0,233 \\
\hline & & AR 3 & $-0,815$ & 0,193 \\
\hline
\end{tabular}




\begin{tabular}{|c|c|c|c|c|}
\hline Bank & Model & Type & Coeff & P-Value \\
\hline & & MA 1 & 106,547 & 0,000 \\
\hline & & Constant & 403,444 & 0,000 \\
\hline & & Mean & 157,362 & _ \\
\hline \multirow{4}{*}{ BPRS X12 } & \multirow{4}{*}{$\operatorname{ARIMA}(2,1,1)$} & AR 1 & $-0,988$ & 0,001 \\
\hline & & AR 2 & $-0,514$ & 0,039 \\
\hline & & MA 1 & $-1,130$ & 0,000 \\
\hline & & Constant & $-0,919$ & 0,044 \\
\hline \multirow{4}{*}{ BPRS XI3 } & \multirow{4}{*}{$\operatorname{ARIMA}(2,1,1)$} & AR 1 & $-1,516$ & 0,000 \\
\hline & & AR 2 & $-0,534$ & 0,013 \\
\hline & & MA 1 & $-101,430$ & 0,000 \\
\hline & & Constant & $-42,1$ & 0,109 \\
\hline \multirow{4}{*}{ BPRS XI4 } & \multirow{4}{*}{$\operatorname{ARIMA}(1,0,1)$} & AR 1 & $-0,020$ & 0,985 \\
\hline & & MA 1 & 0,80 & 0,511 \\
\hline & & Constant & 122,8 & 0,088 \\
\hline & & Mean & 120,4 & _- \\
\hline \multirow{4}{*}{ BPRS X18 } & \multirow{4}{*}{$\operatorname{ARIMA}(1,0,1)$} & AR 1 & $-0,9996$ & 0,000 \\
\hline & & $\mathrm{MA} 1$ & $-0,887$ & 0,230 \\
\hline & & Constant & 8,50 & 0,035 \\
\hline & & Mean & 4,25 & - \\
\hline \multirow{4}{*}{ BPRS X19 } & \multirow{4}{*}{$\operatorname{ARIMA}(2,1,1)$} & AR 1 & $-0,804$ & 0,075 \\
\hline & & AR 2 & 0,195 & 0,608 \\
\hline & & MA 1 & $-0,763$ & 0,038 \\
\hline & & Constant & $-0,25$ & 0,944 \\
\hline \multirow{6}{*}{ BPRS X21 } & \multirow{6}{*}{$\operatorname{ARIMA}(2,0,2)$} & AR 1 & $-0,115$ & 0,536 \\
\hline & & AR 2 & $-1,000$ & 0,000 \\
\hline & & MA 1 & $-0,636$ & 0,021 \\
\hline & & MA 2 & $-0,898$ & 0,002 \\
\hline & & Constant & 10,20 & 0,315 \\
\hline & & Mean & 4,82 & _ \\
\hline \multirow{5}{*}{ BPRS X22 } & \multirow{5}{*}{$\operatorname{ARIMA}(2,1,1)$} & AR 1 & 0,550 & 0,023 \\
\hline & & AR 2 & $-0,415$ & 0,077 \\
\hline & & MA 1 & 0,970 & 0,000 \\
\hline & & Constant & 6,325 & 0,000 \\
\hline & & Mean & 7,310 & - \\
\hline \multirow{6}{*}{ BPRS X23 } & \multirow{6}{*}{$\operatorname{ARIMA}(2,0,2)$} & AR 1 & 0,580 & 0,000 \\
\hline & & AR 2 & $-1,005$ & 0,000 \\
\hline & & MA 1 & 0,549 & 0,156 \\
\hline & & MA 2 & $-0,858$ & 0,032 \\
\hline & & Constant & 27,72 & 0,000 \\
\hline & & Mean & 19,46 & _ \\
\hline
\end{tabular}




\begin{tabular}{|c|c|c|c|c|}
\hline Bank & Model & Tyре & Coeff & P-Value \\
\hline \multirow{5}{*}{ BPRS X26 } & \multirow{5}{*}{$\operatorname{ARIMA}(3,1,1)$} & AR 1 & 0,630 & 0,039 \\
\hline & & AR 2 & 0,238 & 0,442 \\
\hline & & AR 3 & $-0,649$ & 0,021 \\
\hline & & MA 1 & 10,527 & 0,000 \\
\hline & & Constant & $-244,111$ & 0,000 \\
\hline \multirow{4}{*}{ BPRS X28 } & \multirow{4}{*}{$\operatorname{ARIMA}(1,0,1)$} & AR 1 & $-0,285$ & 0,734 \\
\hline & & MA I & 1,362 & 0,036 \\
\hline & & Constant & 136,343 & 0,000 \\
\hline & & Mean & 106,086 & _ \\
\hline \multirow{5}{*}{ BPRS X29 } & \multirow{5}{*}{$\operatorname{ARIMA}(2,0,1)$} & AR 1 & 1,037 & 0,009 \\
\hline & & AR 2 & $-0,610$ & 0,074 \\
\hline & & MA 1 & 0,975 & 0,008 \\
\hline & & Constant & 83,354 & 0,000 \\
\hline & & Mean & 145,562 & - \\
\hline \multirow{5}{*}{ BPRS X30 } & \multirow{5}{*}{$\operatorname{ARIMA}(2,0,1)$} & AR 1 & 1,231 & 0,000 \\
\hline & & AR 2 & $-0,697$ & 0,017 \\
\hline & & MA 1 & 11,507 & 0,000 \\
\hline & & Constant & 823,223 & 0,000 \\
\hline & & Mean & 176,323 & _ \\
\hline \multirow{2}{*}{ BPRS X31 } & \multirow{2}{*}{$\operatorname{ARIMA}(0,1,1)$} & $\mathrm{MA} 1$ & 0,960 & 0,052 \\
\hline & & Constant & 0,2381 & 0,003 \\
\hline \multirow{4}{*}{ BPRS X 32} & \multirow{4}{*}{$\operatorname{ARIMA}(2,1,1)$} & AR 1 & $-1,353$ & 0,003 \\
\hline & & AR 2 & $-0,593$ & 0,054 \\
\hline & & MA 1 & $-1,188$ & 0,034 \\
\hline & & Constant & $-0,1463$ & 0,073 \\
\hline \multirow{3}{*}{ BPRS X33 } & \multirow{3}{*}{ ARIMA(1,1,1) } & AR 1 & 0,836 & 0,006 \\
\hline & & MA 1 & 1,087 & 0,001 \\
\hline & & Constant & $-0,0112$ & 0,471 \\
\hline \multirow{4}{*}{ BPRS X34 } & \multirow{4}{*}{$\operatorname{ARIMA}(2,1,1)$} & AR 1 & 0,567 & 0,061 \\
\hline & & AR 2 & $-0,237$ & 0,437 \\
\hline & & MA 1 & 1,138 & 0,000 \\
\hline & & Constant & 0,05805 & 0,000 \\
\hline \multirow{5}{*}{ BPRS X35 } & \multirow{5}{*}{$\operatorname{ARIMA}(2,0,1)$} & AR 1 & $-0,626$ & 0,059 \\
\hline & & AR 2 & 0,376 & 0,249 \\
\hline & & MA 1 & $-10,320$ & 0,000 \\
\hline & & Constant & 23,29 & 0,000 \\
\hline & & Mean & 18,64 & - \\
\hline \multirow{2}{*}{ BPRS X36 } & \multirow{2}{*}{$\operatorname{ARIMA}(1,1,2)$} & AR 1 & $-0,654$ & 0,097 \\
\hline & & MA 1 & 0,469 & 0,444 \\
\hline
\end{tabular}




\begin{tabular}{|c|c|c|c|c|}
\hline Bank & Model & Type & Coeff & P-Value \\
\hline & & MA 2 & 1,339 & 0,034 \\
\hline & & Constant & $-139,864$ & 0,000 \\
\hline \multirow{7}{*}{ BPRS X37 } & \multirow{7}{*}{$\operatorname{ARIMA}(3,0,2)$} & AR 1 & 1,675 & 0,003 \\
\hline & & AR 2 & $-1,670$ & 0,010 \\
\hline & & AR 3 & 0,609 & 0,375 \\
\hline & & MA 1 & 14,885 & 0,000 \\
\hline & & MA 2 & $-0,538$ & 0,137 \\
\hline & & Constant & 4,795 & 0,000 \\
\hline & & Mean & 12,42 & _ \\
\hline \multirow{4}{*}{ BPRS X38 } & \multirow{4}{*}{$\operatorname{ARIMA}(2,1,1)$} & AR 1 & 1,85 & 0,139 \\
\hline & & AR 2 & $-1,010$ & 0,304 \\
\hline & & MA 1 & 0,787 & 0,306 \\
\hline & & Constant & 10,9 & 0,468 \\
\hline \multirow{4}{*}{ BPRS X39 } & \multirow{4}{*}{$\operatorname{ARIMA}(1,1,2)$} & AR 1 & $-0,977$ & 0,006 \\
\hline & & MA 1 & $-0,048$ & 0,933 \\
\hline & & MA 2 & 0,971 & 0,006 \\
\hline & & Constant & $-0,980$ & 0,000 \\
\hline \multirow{4}{*}{ BPRS X40 } & \multirow{4}{*}{$\operatorname{ARIMA}(2,1,1)$} & AR 1 & $-0,512$ & 0,258 \\
\hline & & AR 2 & $-0,746$ & 0,134 \\
\hline & & MA 1 & 1,116 & 0,000 \\
\hline & & Constant & 0,78583 & 0,000 \\
\hline
\end{tabular}

Sumber: Hasil olah data CAR forecasting, (2018) 